\title{
Early Changes in Bacterial Envelopes after Inhibition of Peptidoglycan Synthesis, as Shown by the Use of a Fluorescent Probe
}

\author{
By H. J. ROGERS* AND G. WRIGHT \\ Biological Laboratory, University of Kent, Canterbury, Kent CT2 $7 N J, U K$
}

(Received 29 October 1986; revised 24 March 1987)

The probe 8-anilino-1-naphthalene sulphonate (ANS) showed increasing fluorescence with Bacillus subtilis metClyt-2 cells taken from exponentially growing cultures treated with antibiotics that inhibit cell-wall peptidoglycan synthesis. This increase was due to the probe reaching hydrophobic cell constituents, probably membranes, and started within $30 \mathrm{~min}$ of the addition of the antibiotics. This corresponded to the time at which membrane function had been shown to be damaged. The increased fluorescence of the cells with ANS persisted after removal of the antibiotics.

\section{INTRODUCTION}

Antibiotics such as $\beta$-lactams or cycloserine that inhibit peptidoglycan biosynthesis are bactericidal and lead to the lysis of growing cultures of many bacteria, but for other species of bacteria they are bactericidal yet do not cause perceptible lysis. The relation between the possession and action of autolysins and the death of antibiotic-treated bacteria has been the subject of much work and speculation (Tomasz, 1979; Shockman et al., 1979, 1981; Rogers et al., 1980, 1983; Lopez et al., 1976; Sanchez-Puelles et al., 1986) but the situation is still unclear. Mutants of Bacillus subtilis deficient in autolysins were not lysed significantly by $\beta$-lactams as measured by optical density, leakage of protein or the formation of soluble wall constituents (Rogers et al., 1983) but the bacteria died, suffering what has been called non-lytic death (Shockman et al., 1981). Early damage to membrane functions was shown but wall changes allowing penetration of cationized ferritin particles could only be seen much later and in rare cells. The present paper reports an early change in $\beta$-lactam-treated, autolysin-deficient $B$. subtilis that is best attributed to a change in the permeability of the cell walls.

\section{METHODS}

Micro-organisms and growth media. Two autolysis-deficient mutants were used: FJ6 (metC3 lyt-2) (Fein \& Rogers, 1976) and 109 (metC3 lyt-2 $\left.\mathrm{TOL}^{+}\right)$. The latter was one of a number of mutants selected from strain FJ6 after mutagenesis with ethylmethane sulphonate as surviving on beef heart infusion medium (Difco) containing $5 \mu \mathrm{g}$ cephalothin $\mathrm{ml}^{-1}$ but not forming colonies on media containing $0.1 \mu \mathrm{g} \mathrm{ml}^{-1}$. The MIC for cephalothin was about $0.05 \mu \mathrm{g} \mathrm{ml}^{-1}$ when freshly isolated as was that of strain FJ6. This has increased slightly to between 0.05 and $0.1 \mu \mathrm{g} \mathrm{ml}^{-1}$ over a period of 4 years. Strain 109 was susceptible to rapid lysis by added purified autolysins or lysozyme. Its rates of lysis when antibiotics were added to cultures were much slower than those of FJ6 as were rates of lysis of suspensions at either $\mathrm{pH} \mathbf{9 \cdot 0}$ or $\mathbf{5 \cdot 5}$. Extracts from cells made with $5 \mathrm{M}-\mathrm{LiCl}$ were too low in activity for quantitative measurement. Its rate of cell autolysis in suspension has increased somewhat over the years but it still lysed at about 10 to $20 \%$ of the rate of FJ6 when grown on beef heart medium (H. J. Rogers \& S. Raytor, unpublished work; Rogers \& Wright, 1986). Precautions have been found to be necessary to avoid all measurable lysis of both strain FJ6 and strain 109 when treated with antibiotics. Spore suspensions were carefully freed of vegetative debris by adequate lysozyme treatment and repeated washing with buffer. They were stored at $-10^{\circ} \mathrm{C}$ and only small samples were thawed for use in the automatic inoculator (Rogers \& Wright, 1986). The growth

Abbreviations: ANS, 8-anilino-1-naphthalene sulphonate; PMSF, phenylmethylsulphonyl fluoride. 
media were CHSC and MSM (Rogers et al., 1983; Rogers \& Thurman, 1985). The behaviour of FJ6 with $\beta$-lactam antibiotics in these media was found to differ. Whereas in MSM medium the concentrations of $\beta$-lactams had to be carefully chosen to avoid a very slow lysis subsequent to their addition, in CHSC medium the concentrations could be increased at least twentyfold beyond that necessary just to stop growth without perceptible lysis occurring for at least $8 \mathrm{~h}$. In $24 \mathrm{~h}$ the optical density of CHSC cultures treated with cephalothin was reduced by only about $10 \%$. Cultures were grown in side-arm flasks of five times the volume of medium at $35^{\circ} \mathrm{C}$ in an orbital incubator. Measurement of growth and lysis in cultures. $\mathrm{OD}_{675}$ was used as described by Rogers \& Wright (1986).

Preparation of SDS-walls. Bacterial cell walls free of protein and lipid were prepared as by Fein \& Rogers (1976).

Fluorescence measurements. Samples were taken of sufficient volume eventually to provide two $1 \mathrm{ml}$ suspensions of $\mathrm{OD}_{675}$ about 0.600 . The samples were filtered through $0.45 \mu \mathrm{m}$ membranes, the bacteria washed with twice the

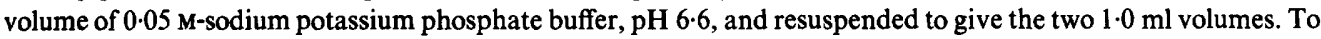
one of these was added $2.0 \mathrm{ml}$ and to the other $1.85 \mathrm{ml}$ of the same phosphate buffer together with $150 \mu \mathrm{l} 1 \mathrm{mM}-8$ anilino-1-naphthalene sulphonate (ANS). The fluorescence of both samples was measured in a $1 \mathrm{~cm}$ glass cuvette at $25^{\circ} \mathrm{C}$ in a Perkin-Elmer MPF3 fluorimeter using an excitation wavelength of $370 \mathrm{~nm}$, an emission wavelength of $475 \mathrm{~nm}$, and slit widths of $8 \mathrm{~nm}$. The $\mathrm{OD}_{675}$ of the samples was also recorded. The instrument was standardized daily by measuring the fluorescence of $5 \mu \mathrm{M}$-ANS in ethanol and the results corrected for any change in the value obtained. The fluorescence readings for the bacterial sample containing ANS $\left(R_{\text {ANS }}\right)$ were also corrected for the value obtained for the sample not containing ANS, which measured scattered light $\left(R_{\mathrm{S}}\right)$, and for the fluorescence of $50 \mu \mathrm{M}$-ANS in $0.05 \mathrm{M}$-sodium potassium phosphate buffer $\mathrm{pH} 6.6\left(\mathrm{ANS}_{\mathrm{Aq}}\right)$, itself corrected for light absorption using its inner filter factor (IFF). The fluorescence intensity $F$ was then

$$
\left[\frac{\left[\left(R_{\mathrm{ANS}}-R_{\mathrm{S}}\right)-\mathrm{ANS}_{\mathrm{Aq}}\right] \mathrm{IFF}}{\mathrm{OD}_{675} \times 0.5}\right] \cdot \frac{485}{\mathrm{ANS}_{\mathrm{Alc}}}
$$

where 485 was the value initially obtained as the fluorescence of $5 \mu \mathrm{M}$-ANS in absolute ethanol and ANS $_{\mathrm{Alc}}$ the value obtained in the particular experiment. The IFF was measured as

$$
\text { antiln }\left[\frac{\mathrm{OD}_{370}+\mathrm{OD}_{475}}{2}\right]
$$

Preparation of membranes. Bacteria were incubated for $2 \mathrm{~h}$ at $35^{\circ} \mathrm{C}$ in $0.05 \mathrm{M}$-sodium potassium phosphate buffer, $\mathrm{pH} 6 \cdot 6$, containing $50 \mu \mathrm{g}$ lysozyme $\mathrm{ml}^{-1}, 10 \mu \mathrm{g}$ deoxyribonuclease $\mathrm{ml}^{-1}, 10 \mu \mathrm{g}$ ribonuclease $\mathrm{ml}^{-1}$ and, in some experiments, $10 \mu \mathrm{g}$ phenylmethylsulphonyl fluoride (PMSF) $\mathrm{ml}^{-1}$. The digest was then centrifuged $\left(100000 \mathrm{~g}\right.$ for $30 \mathrm{~min}$ at $\left.4^{\circ} \mathrm{C}\right)$ and the pellet taken as the membrane fraction of the cells. The supernatant was called the cytosol.

\section{RESULTS}

\section{Fluorescence of exponentially growing FJ6 with ANS}

Solutions of ANS in $0.05 \mathrm{M}$-sodium potassium phosphate buffer, pH 6.6, had a weak fluorescence with an emission maximum of $520 \mathrm{~nm}$. As the concentration of bacteria present in such solutions was increased up to $100 \mu \mathrm{g}_{\text {dry }} \mathrm{wt} \mathrm{ml}^{-1}$ (equivalent to an $\mathrm{OD}_{675}$ of $0 \cdot 2$ ) the fluorescence increased and the emission maximum shifted towards $475 \mathrm{~nm}$. No further shift from $475 \mathrm{~nm}$ occurred with higher bacterial concentrations but the fluorescence intensity was increased. Within the range of $\mathrm{OD}_{675} 0.02$ to 0.30 fluorescence was proportional to bacterial mass. It was also proportional to ANS concentration providing the appropriate inner filter corrections were made. The reduced wavelength of the emission spectrum is characteristic of ANS in an hydrophobic environment. Membrane preparations made from strains FJ6 and 168 were suspended in phosphate buffer and $50 \mu \mathrm{M}$-ANS added; the maximum in the emission spectrum was also at $475 \mathrm{~nm}$. Cell wall preparations (SDS-cell walls) did not significantly increase the fluorescence of ANS in phosphate buffer (Table 1) nor shift the emission maximum. The fluorescence intensity of the membranes was 1420 per $\mathrm{mg}$ membrane protein and the membrane content per mg dry wt bacterial cells showed that the fluorescence of the bacteria was only $16 \%$ of that calculated if the probe had reacted with all the cell membrane. Further evidence that the fluorescence of ANS with the bacteria was due to reaction with membranes was provided by varying the $\mathrm{pH}$ of the suspension buffer. The fluorescence of ANS with membrane preparations is known to be greatly influenced by $\mathrm{pH}$ and ionic strength (Freedman $\&$ Radda, 1969). When the $\mathrm{pH}$ was varied from 3.0 to 10.0 using either FJ6 bacteria or 


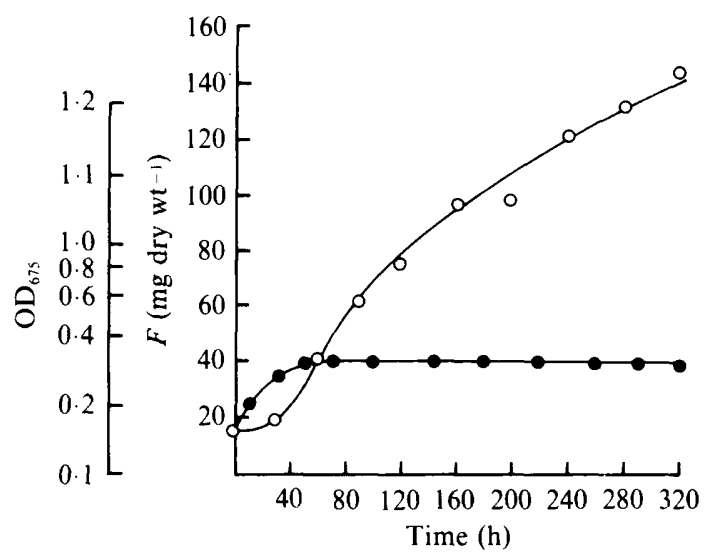

Fig. 1. Increase in fluorescence with ANS during treatment of strain FJ6 with cephalothin. Strain FJ6 was grown on CHSC medium and at time zero $0.2 \mu \mathrm{g}$ cephalothin $\mathrm{ml}^{-1}$ was added. At the times indicated samples were withdrawn and the $\mathrm{OD}_{675}(\bullet)$ and the fluorescence $(F)$ with ANS $(O)$ measured as described in Methods.

membranes isolated from them, the effects on both samples were identical. The absolute values were five to six times higher for the membranes than for the bacteria.

\section{Effect of antibiotics on the fluorescence of ANS with whole bacteria}

A concentration of $0.2 \mu \mathrm{g}$ cephalothin $\mathrm{ml}^{-1}$ was added to exponentially growing cultures of strain FJ6 in CHSC medium and samples were taken at regular intervals, filtered, and the bacteria washed and resuspended in phosphate buffer with and without $50 \mu \mathrm{M}$-ANS as described in Methods. The fluorescence with ANS started to increase about 20-30 min after adding the antibiotic and continued to do so for about $6 \mathrm{~h}$ by which time the fluorescence per $\mathrm{mg}$ bacterial dry wt was about six to seven times the value for control cells (Fig. 1). Increasing the concentration of cephalothin to $1 \mu \mathrm{g} \mathrm{ml}^{-1}$ had little effect on either the rate of development or final intensity of fluorescence. When FJ6 was grown in MSM medium and 0.05 $\mu \mathrm{g}$ cephalothin $\mathrm{ml}^{-1}$ added the results were similar but the rise in fluorescence started slightly later at $30-40 \mathrm{~min}$ after adding the antibiotic. Addition of $0 \cdot 2 \mu \mathrm{g}$ cephalothin $\mathrm{ml}^{-1}$ to strain 109 in CHSC medium led to a much longer period before growth stopped and a much greater increase in $\mathrm{OD}_{675}$, being 2-3 times that obtained with FJ6. Under these conditions fluorescence did not start to increase for 60-70 min and then rose much more slowly than with FJ6 but if the concentration of antibiotic was increased to $1 \mu \mathrm{g} \mathrm{ml}^{-1}$ the kinetics of growth and fluorescence increase for FJ6 and 109 were identical. The relationship, if any, between this behaviour of strain 109 and its slight increase in resistance to cephalothin is unknown. Cycloserine added at a concentration of $330 \mu \mathrm{g} \mathrm{ml}^{-1}$ inhibited growth of exponential cultures of FJ6 and the increase in fluorescence of ANS was identical to that given by cephalothin. A range of $\beta$-lactam antibiotics behaved similarly whereas antibiotics that did not interfere with wall synthesis at concentrations sufficient to stop growth, such as chloramphenicol, erythromycin, spectinomycin and kanamycin, caused no increase of fluorescence with ANS.

Although no reduction occurred in $\mathrm{OD}_{675}$ during many hours treatment of the mutants in the CHSC medium with cell-wall-inhibiting antibiotics, this did not exclude actions of autolysins too slight to cause bacterial rupture but sufficient to modify the cell walls so that they were more permeable to ANS. If so, methods which either increased or decreased cell autolysis might have been expected to alter the fluorescence of bacteria with ANS. Both cerulenin and 1-alkanols added to the growth medium for strain 168 reduce cell autolysis (Rogers \& Thurman, 1985; Rogers \& Wright, 1986). The addition of neither $3 \mu \mathrm{g}$ cerulenin $\mathrm{ml}^{-1}$ nor $0.7 \mathrm{M}$-ethanol to cultures of FJ6 $30 \mathrm{~min}$ before $0.2 \mu \mathrm{g}$ cephalothin $\mathrm{ml}^{-1}$ affected the rate of development or final intensity of fluorescence with ANS. 
Table 1. ANS fluorescence with cell fractions and with strain FJ6 treated with cephalothin

Strain FJ6 was grown on CHSC medium and treated with $0.2 \mu \mathrm{g}$ cephalothin $\mathrm{ml}^{-1}$. The lysozyme digest and the cell fractions were prepared as described in Methods. The results are expressed as fluorescence per $\mathrm{mg}$ dry wt bacteria $\pm \mathrm{SD}$. The number of independent determinations is given in parentheses.

\begin{tabular}{|c|c|c|}
\hline & \multicolumn{2}{|c|}{ Fluorescence } \\
\hline & -PMSF & +PMSF \\
\hline Untreated bacteria & $25 \cdot 0 \pm 23 \cdot 5(19)$ & \\
\hline \multicolumn{3}{|l|}{ Cephalothin treated bacteria } \\
\hline $\begin{array}{l}3 \mathrm{~h} \\
5 \mathrm{~h}\end{array}$ & $\begin{array}{l}93.4 \pm 6.4(3) \\
138\end{array}$ & $\begin{array}{r}98 \\
130\end{array}$ \\
\hline Lysozyme digest & $211 \pm 31 \cdot 5(10)$ & $336.6 \pm 45.9(4)$ \\
\hline Membranes & $105 \cdot 5 \pm 16 \cdot 7(3)$ & 212 \\
\hline Cytosol & $92 \cdot 8 \pm 23 \cdot 3(3)$ & $124 \cdot 2$ \\
\hline \multicolumn{3}{|l|}{ Cell walls } \\
\hline Untreated cells & $0 \pm 2 \cdot 6(3)$ & - \\
\hline Cephalothin treated cells & $12 \cdot 8,13 \cdot 3$ & - \\
\hline
\end{tabular}

\section{Persistence of fluorescent effect}

A sub-inhibitory concentration of cephalothin $\left(0.03 \mu \mathrm{g} \mathrm{ml}^{-1}\right)$ added to exponentially growing cultures of FJ6 in MSM medium caused a temporary reduction in growth rate after $1 \mathrm{~h}$ which lasted for a further 1-2 $\mathrm{h}$. The fluorescence of the bacteria with ANS was measured $2 \mathrm{~h}$ after adding cephalothin and the whole culture was then filtered through a $0.45 \mu \mathrm{m}$ pore membrane, the bacteria washed with a large volume of warm medium not containing antibiotic, and resuspended in more of the same medium at $35^{\circ} \mathrm{C}$. Growth accelerated within $1 \mathrm{~h}$ to the same rate as a culture that had not been treated with antibiotic. Samples were taken at frequent intervals for measurement of fluorescence with ANS. After the period of accelerating growth, the fluorescence intensity declined exponentially but at about half the rate calculated by simple dilution of the original antibiotic-treated cells. The observed half-life for the decay was $175 \mathrm{~min}$ whereas the calculated value was $80 \mathrm{~min}$ which is longer than the doubling time of the bacteria which was $65 \mathrm{~min}$ due to allowance made for the fluorescence of the growing population of new undamaged cells.

\section{Fluorescence of bacterial components with ANS}

The fluorescence given with ANS by lysozyme digests, membranes and intracellular soluble components (see Methods) was increased if the protease inhibitor PMSF was present during digestion (Table 1). If membrane preparations were treated briefly with trypsin in the absence of PMSF fluorescence with ANS was greatly reduced. Inclusion of up to $5 \mathrm{mM}-\mathrm{PMSF}$ in the culture medium during treatment of FJ6 with cephalothin, however, failed to alter the fluorescence of the cells with ANS. If as seems likely the proteases were only able to act on cell components after disruption, the fluorescence results for the cephalothin-treated cells should be compared with those for cell fractions prepared in the presence of PMSF. Then the value for the cells treated with antibiotic for 5-6 h was lower than that given by the membrane they contained. The cell walls isolated from control cells showed no fluorescence with ANS whereas those from bacteria treated for $3 \mathrm{~h}$ with cephalothin showed a just-detectable signal; however, this was too small for exact measurement. As can be seen measurement of the control cells themselves was difficult and subject to high variation because of the small signal emitted.

\section{DISCUSSION}

Earlier work (Cramer \& Phillips, 1970; Cramer et al., 1973; Phillips \& Cramer, 1973; Helgerson \& Cramer, 1977; Nieva-Gomez \& Gennis, 1977; Nieva-Gomez et al., 1976) with Escherichia coli showed that fluorescence with various probes was increased and the emission wave-length peak reduced when the bacteria were deprived of energy source or treated with 
colicin E1. The general conclusion from the work was that the change in the fluorescence was due to an alteration in the organization or conformation of the bacterial cell envelope (NievaGomez \& Gennis, 1977; Phillips \& Cramer, 1973). The present work describes a similar change in fluorescence with ANS when the Gram-positive B. subtilis strain FJ6 was treated with antibiotics that inhibit cell-wall synthesis. The increased fluorescence of the probe started within $30 \mathrm{~min}$ of the addition of the antibiotics while the biomass in the culture was still increasing and at the same time as membrane damage became apparent (Rogers et al., 1983). Unlike Gram-negative organisms in which the lipopolysaccharides and outer membranes are known to exclude hydrophobic substances (Nikaido \& Vaara, 1985) the walls of Gram-positive organisms might have been expected to be permeable to ANS which is a negatively charged amphipathic molecule of $M_{\mathrm{r}} 310.5$. The fixed negative charges in the walls do not seem to play a major role in its exclusion since wide variations in $\mathrm{pH}$ affected fluorescence intensity in the same way as for isolated membranes. Two possibly interrelated processes might have led to increased contact between the probe and hydrophobic cell contents. Some hydrolysis of peptidoglycan bonds by the residual autolysins present in all autolytic-deficient mutants so far isolated might have made the wall more porous. Growth under conditions further depressing cell autolysis by the mutants may still have left enough active enzyme. Additionally, however, hydrophobic cell constituents might have emerged into the altered walls. A number of species which show no loss of optical density when treated with antibiotics inhibiting wall synthesis excrete phospholipids, albeit at very different rates (Horne \& Tomasz, 1977; Brissette et al., 1982; Rogers et al., 1983). Moreover, phospholipid turnover increased at the same time as fluorescence with ANS started to increase (Rogers et al., 1983). Indeed, whole membrane vesicles have been claimed to be excreted by autolysin-defective strains of pneumococci treated with benzylpenicillin (Hakenbeck et al., 1978) although this did not occur with the $B$. subtilis mutants. The known peripheral location in membranes of probes like ANS (Azzi, 1975), and the importance of membrane proteins in their fluorescence, makes emergence of membrane proteins rather than phospholipids into the walls a more likely cause of the phenomenon.

The authors gratefully acknowledge the help of a Medical Research Project Grant in this work.

\section{REFERENCES}

AzzI, A. (1975). The application of fluorescent probes in membrane studies. Quarterly Review of Biophysics 8, 237-316.

Brissette, J. L., Shockman, G. D. \& Pieringer, R. A. (1982). Effects of penicillin on synthesis and excretion of lipid and lipoteichoic acid from Streptococcus mutans BH7. Journal of Bacteriology 151, 838-824.

Cramer, W. A. \& Phillips, S. K. (1970). Response of an Escherichia coli-bound fluorescent probe to colicin E1. Journal of Bacteriology 104, 819-825.

Cramer, W. A., Phillips, S. K. \& Keenan, T. W. (1973). On the role of the membrane phase in the transmission mechanism of colicin E1. Biochemistry 12, 1177-1181.

FeIN, J. E. \& Rogers, H. J. (1976). Autolytic enzyme deficient mutants of Bacillus subtilis 168. Journal of Bacteriology 127, 1427-1442.

FreedMan, R. A. \& RADDA, G. K. (1969). Interaction of 1-anilino-8-naphthalene sulphonate with erythrocyte membranes. FEBS Letters 3, 150-152.

HAKENBECK, R., WAKs, S. \& TOMASZ, A. (1978). Characterisation of cell wall polymers secreted into the growth medium of lysis-defective pneumococci during treatment with penicillin and other inhibitors of cell wall synthesis. Antimicrobial Agents and Chemotherapy 13, 302-311.

Helgerson, S. L. \& Cramer, W. A. (1977). Changes in Escherichia coli cell envelope structure and sites of fluorescence probe binding caused by carbonyl cyanide $p$-trifluoromethoxyphenyl hydrazone. Biochemistry 16, 4109-4116.

HORNE, D. \& TOMASZ, A. (1977). Tolerant response of Streptococcus sanguis to $\beta$-lactams and other cell wall inhibitors. Antimicrobial Agents and Chemotherapy 11, 888-896.

Lopez, R., Sanchez-Puelles, J. M. \& Garcia, P. (1976). Isolation, characterization and physiological properties of an autolytic-deficient mutant of Streptococcus pneumoniae. Molecular and General Genetics 204, 237-242.

Nieva-Gomez, D. \& GenNis, R. B. (1977). Affinity of intact Escherichia coli for hydrophobic membrane probes is a function of the physiological state of the cells. Proceedings of the National Academy of Sciences of the United States of America 74, 1811-1815.

Nieva-Gomez, D., Konisky, J. \& GenNIS, R. B. (1976). Membrane changes in Escherichia coli induced by colicin la and agents known to disrupt energy transduction. Biochemistry 15, 2747-2753.

Nikaido, H. \& VAara, M. (1985). Molecular basis of bacterial outer membrane permeability. Microbiological Reviews 49, 1-32.

Phillips, S. K. \& Cramer, W. A. (1973). Properties of the fluorescent probe response associated with the transmission mechanism of colicin E1. Biochemistry 12, $1170-1176$. 
Rogers, H. J. \& Thurman, P. F. (1985). The effect of cerulenin on the morphogenesis and autolytic activity of Bacillus subtilis. Journal of General Microbiology 131, 591-599.

ROGERS, H. J. \& WRIGHT, G. (1986). Effects of ethanol and other 1-alkanols on cell autolysis and macromolecular synthesis by Bacillus subtilis. Journal of General Microbiology 132, 1221-1229.

Rogers, H. J., Perkins, H. R. \& Ward, J. B. (1980). Microbial Cell Walls and Membranes. London: Chapman \& Hall.

Rogers, H. J., Thurman, P. F. \& Burdett, J. D. J. K. (1983). The bactericidal action of $\beta$-lactam antibiotics on an autolysis-deficient strain of Bacillus subtilis. Journal of General Microbiology 129, 465-478.

Sanchez-Puelles, J. M., Ronda, C., Garcia, J. L., Garcia, P., LOPEZ, R. \& GARCIA, E. (1986).
Searching for autolysin functions - characterisation of a pneumococcal mutant deleted on the $l y t A$ gene. European Journal of Biochemistry 158, 289-293.

Shockman, G. D., Daneo-Moore, L., CornetT, J. B. \& Mychajlonka, M. (1979). Does penicillin kill bacteria? Reviews of Infectious Diseases 1, 787-796. Shockman, G. D., DANEo-MoORE, L., McDowell, T. D. \& WONG, W. (1981). Function and structure of the cell wall - its importance in the life and death of bacteria. In $\beta$-Lactam Antibiotics. Mode of Action, New Developments and Future Prospects, pp. 31-35. Edited by M. Salton \& G. D. Shockman. New York \& London: Academic Press.

Tomasz, A. (1979). The mechanism of the irreversible antimicrobial effects of penicillin: how the $\beta$-lactam antibiotics kill and lyse bacteria. Annual Review of Microbiology 33, 113-139. 